\title{
The ACM Future of Computing Academy
}

One of my priorities as ACM president is to have our organization effectively engage with younger practitioners, researchers, educators, and entrepreneurs across

the global computing community. In my first column last August, I noted that new supporting initiatives were being formulated. I am now pleased to announce the establishment of the ACM Future of Computing Academy (ACM-FCA), created to bring together talented young professionals from various computing disciplines to address the most pressing challenges facing the field and society at large.

ACM's longtime members and our traditional activities have helped grow our field and have contributed to the enormous impact computing has made on our lives. We will look to the ACM-FCA members to lead the way in showing us how we might develop new models for participation, collaboration, and career support. In short, members of the Academy will engage in activity for the benefit of their own and future generations.

When I took office in July, I asked Matthias Kaiserswerth (Hasler Stiftung, Switzerland) and Aaron Quigley (University of St. Andrews, Scotland) to consider how ACM might better engage young computing professionals. They have taken on this challenge and conducted a wide-ranging consultation with existing academies, ACM executives, ACM Council, Europe Council, ACM SIGs, and others. Based on their recommendations, the ACM Council has voted to establish this new Future of Computing Academy.

The FCA will seek to harness collective action to define and launch new
ACM initiatives that will carry us into the future. Academy members will have the satisfaction of contributing to our field while enjoying the opportunity to grow their personal networks across all regions, computing disciplines, and computing professions. Academy members will be supported by an extended network of more senior mentors, ACM leadership, and recognized thought leaders in computing.

Given the FCA goals, we anticipate that members of the Academy will reflect the global diversity in computing and typically be in their $20 \mathrm{~s}$ to early 30s upon application to the Academy. Members will have already demonstrated great professional promise, and should be eager to come together to engage in this work. Members of the academy are expected to participate in activities for the

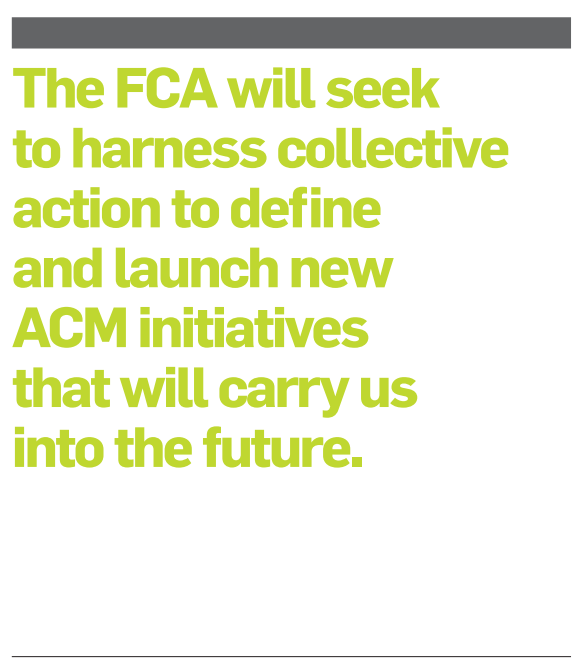

benefit of their generation as they build and shape new experiences to advance computing.

If you are a young computing professional, you may recognize the opportunity that joining this Academy presents. Perhaps your current work as a researcher, practitioner, entrepreneur, or educator has given you insights into what problems ACM should be tackling, how the field of computing should evolve, how ACM should adapt to the needs of future generations, and where computing can help address the global issues we all face. If so, and if you have the desire to come together with like-minded individuals from around the world, then this Academy is for you.

Or perhaps you are a more established computing professional. If you wish to support this goal of developing fresh perspectives, then consider encouraging suitable candidates to apply.

The ACM-FCA will be taking applications at http://www.acm.org/fca through 15 March of 2017, with Matthias Kaiserswerth and Aaron Quigley serving as the initial convening committee. The Academy will be self-governing and will establish an elected executive committee.

It is important to note that membership in the Academy is a service commitment, not an award. Active participation is essential to Academy membership. The inaugural meeting of the ACM-FCA will be on 25 June 2017 in San Francisco. Members of the Academy will also be invited to attend the "50 Years of the ACM Turing Award" conference that precedes this meeting.

We look forward to the establishment of the Academy and to welcoming its first cohort of members in 2017.

\footnotetext{
Vicki L. Hanson (vlh@acm.org) is ACM President, Distinguished Professor at Rochester Institute of Technology, and a professor at the University of Dundee. Twitter: @ACM_President. 